\title{
Natural incidence of bean viruses in the northwest of Iran
}

\author{
Masoumeh JALALI ${ }^{1}$, Mina RASTGOU*
}

Received January 23, 2017; accepted June 01, 2017.

Delo je prispelo 23. januarja 2017, sprejeto 01. junija 2017.

\begin{abstract}
Bean is considered as one of the most important legumes around the world. Viral diseases are a major yield reducing factor in bean production. Bean samples with virus-like symptoms like severe or mild mosaic, vein banding, leaf curling, blistering and necrosis were collected from different bean fields in Urmia (Northwest of Iran) during the growing seasons of 2013 and 2014. Bean common mosaic virus (BCMV), Bean common mosaic necrosis virus (BCMNV), Bean yellow mosaic virus (BYMV), Cucumber mosaic virus (CMV), Tomato spotted wilt virus (TSWV), Tomato mosaic virus (ToMV) and Tomato yellow leaf curl virus (TYLCV) were detected by double antibody sandwich enzyme-linkedimmunosorbent assay. Mixed infection of BCMV and $\mathrm{BCMNV}$ were found. BCMNV was the most frequent virus in this region whereas BYMV and TYLCV were each detected just in one sample. This is the first report of BCMNV, BCMV, BYMV, TSWV, TMV and TYLCV incidence on bean in Urmia, Iran.
\end{abstract}

Key words: BCMV; BYMV; BCMNV; TYCLV; TMV; TSWV; Iran; ELISA

\section{IZVLEČEK \\ RAZŠIRJENOST VIRUSOV FIŽOLA V SEVEROZAHODNEM IRANU}

Fižol je ena izmed najpomembnejših stročnic širom po svetu. Virusne bolezni so najpomembnejši dejavnik zmanjševanja njegovega pridelka. Vzorci fižola $\mathrm{z}$ znamenji virusnih ukužb kot so blagi ali izraziti mozaik, obžilna razbarvanja, zvijanje, mehurjavost in nekroza listov so bili nabrani $\mathrm{z}$ različnih fižolovih polj v okolici Urmie (severozahodni Iran) v rastnih sezonah 2013 in 2014. Virus navadnega mozaika fižola (BCMV), virus navadnega mozaika in nekroze fižola (BCMNV), virus rumenega mozaika fižola (BYMV), virus mozaika kumar (CMV), virus pegavosti in uvelosti paradižnika (TSWV), virus mozaika paradižnika (ToMV) in virus rumenenja in kodravosti paradižnika (TYLCV) so bili ugotovljeni z ELISA testom. Najdena je bila mešana okužba z BCMV in BCMNV. BCMNV je bil najpogostejši virus na tem območju, medtem, ko sta bila BYMV in TYLCV ugotovljena samo v po enem vzorcu. To je prvo poročanje o pojavljanju BCMNV, BCMV, BYMV, TSWV, TMV in TYLCV na fižolu v Urmiji, Iran.

Ključne besede: BCMV; BYMV; BCMNV; TYCLV; TMV; TSWV; Iran; ELISA

\section{INTRODUCTION}

The common bean (Phaseolus vulgaris L.) is one of the major food legumes produced on over 26 million hectares worldwide (Mavrič and Šustar-Vozlič, 2004; Loebenstein et al., 2009). Virus diseases are a major yield reducing factor in bean production. Thirty four different virus species have been reported to infect common bean naturally (Arli-Sokman et al., 2016). Economically the most important viruses are potyviruses including Bean common mosaic virus (BCMV), Bean common mosaic necrosis virus (BCMNV) and Bean yellow mosaic virus (BYMV). Other important viruses on bean are Cucumber mosaic virus (CMV), Southern bean mosaic virus (SBMV), Tobacco streak virus (TSV) and Tomato aspermy virus (TAV) (Brunt et al., 1996; Kumar et al., 1994). These viruses are transmitted by insect vectors, mainly aphids with the exception of TSV that is transmitted by thripses and SBMV that is transmitted by been leaf beetle. Some of them can be transmitted by seed (Loebenstein et al., 2009). Insect transmission is very important for virus spread on short distances while seed transmission is the most important factor in the spread of viruses around the world. Because of the high seed transmission rate (up to $83 \%$ ), BCMV and BCMNV are economically the

\footnotetext{
1 Department of Plant Protection, College of Agriculture, Urmia University, Urmia, Iran

* Department of Plant Protection, College of Agriculture, Urmia University, Urmia, Iran, Po. Box: 165, Iran; email: m.rastgou@ urmia.ac.ir
} 
most important viruses of common bean (Mavrič and Šustar-Vozlič, 2004). For example, BCMV can reduce yield up to $24 \%$ (Kumar et al., 1994). BCMV, BYMV and BCMNV have been reported from bean-growing regions of Iran (Kaiser and Mossahebi, 1974; Shahraeen et al., 2002; Shahraeen et al., 2005; Peyambari et al., 2011; Ghasemzadeh et al., 2012; Ghobakhloo et al., 2012; Salari et al., 2013). Other viruses reported on bean from Iran include Alfalfa mosaic virus (AMV), Tobacco mosaic virus (TMV), Tomato mosaic virus (ToMV), Bean leaf roll virus (BLRV), Soybean mosaic virus (SMV), Bean pod mottle virus (BPMV), Bean curly top virus (BCTV), Broad bean wilt virus (BBWV), Broad bean stain virus (BBSV) and Faba bean necrotic yellows virus (FBNYV) (Kaiser and
Mossahebi, 1974; Shahraeen et al., 2005; Alavi and Massumi, 2014). BCMV has been recognized as a major constraint on bean production in Iran. Bean is one of the most important cultivated crop in West Azarbaijan province covering around 1346 ha with the mean yield of $2 \mathrm{t} \mathrm{ha}^{-1}$, but until now there was no data on viral diseases of this crop in this region. The occurrence, frequency and distribution of seven viruses including BCMV, BCMNV, BYMV, CMV, Tomato spotted wilt virus (TSWV), Tomato mosaic virus (ToMV) and Tomato yellow leaf curl virus (TYLCV) in bean growing areas of Urmia, the largest bean growing region in West Azarbaijan province were studied in 2013 and 2014 and are presented in the article.

\section{MATERIALS AND METHODS}

\subsection{Plant material}

A set of 195 symptomatic samples of bean showing severe or mild mosaic, vein banding, leaf curling, blistering and necrosis on leaves was collected from bean growing areas of Emamzadeh-Gharachelar, Ghafar Behi, Jabal, Balo, Nazloo (Urmia University campus) and Aliabad regions around the city of Urmia during the 2013 and 2014 growing seasons. Each sample was put in a plastic bag, labelled and stored at $4{ }^{\circ} \mathrm{C}$.

\subsection{Virus detection}

Double antibody sandwich enzyme linked immunosorbent assay (DAS-ELISA) was used for detection of BYMV, BCMV, BCMNV, TSWV, CMV, ToMV, TYLCV according to Clark and Adams (1977) method with minor changes using commercial polyclonal antisera obtained from DSMZ (Braunschweig, Germany). ELISA plates were coated with coating buffer containing anti-BCMV, BYMV, BCMNV, TSWV, CMV, ToMV and TYLCV polyclonal antibodies $(1: 1000)$ and the plates were incubated at $37^{\circ} \mathrm{C}$ for $3 \mathrm{~h}$. Each sample was diluted 1:5 with extraction buffer $\left(8 \mathrm{~g} \mathrm{NaCl}, 0.2 \mathrm{~g} \mathrm{KH}_{2} \mathrm{PO}_{4}, 0.2 \mathrm{~g}\right.$ $\mathrm{NaN}_{3}, 0.5 \mathrm{ml}$ Tween 20 and $2 \%$ PVP in 11 of distilled $\mathrm{H}_{2} \mathrm{O}, \mathrm{pH}$ 7.4). The diluted plant sap extracts were added to the wells $(100 \mu \mathrm{l})$. Two replicates were used for each sample. Plates were kept at $4{ }^{\circ} \mathrm{C}$ overnight, then rinsed three times with washing buffer. Conjugated polyclonal antibody was diluted (1:1000) in conjugate buffer and was loaded into each well. The plate was incubated at $37^{\circ} \mathrm{C}$ for $3 \mathrm{~h}$. Finally, $10 \mathrm{mg}$ of p-nitrophenyl phosphate (Sigma) in $10 \mathrm{ml}$ of substrate buffer was added to the wells and incubated at room temperature for 30-60 min. Absorbance values were read at $405 \mathrm{~nm}$ (A405) using a microplate reader (BioTek ELX-808, USA). Healthy plants were used as negative controls and samples were considered to be positive when the absorbance values at $405 \mathrm{~nm}$ values exceeded at least tree time the mean of the negative controls.

\subsection{Maintenance of the viruses}

Bean plants were planted in pots in a greenhouse and inoculated with virus isolate prepared from systemically infected leaves macerated in a chilled sterilized $0.01 \mathrm{M}$ cold phosphate buffer $\left(\mathrm{K}_{2} \mathrm{HPO}_{4}+\mathrm{KH}_{2} \mathrm{PO}_{4}\right)$, pH 7.0 (1 : $6[\mathrm{w} / \mathrm{v}]$ tissue : buffer). Inoculation on plants at the three-leaf stage was done using the rub method on carborundum-dusted leaves. The plants were observed weekly for symptom development for 5 weeks and samples for DAS-ELISA were taken at each observation time.

\section{RESULTS AND DISCUSSION}

During summer of 2013 and 2014, 195 bean samples with virus-like symptoms such as mosaic on leaves, leaf distortion, downward curling, mottling, vein necrosis and local lesions (Figure 1) were collected from bean farms in different areas and villages around Urmia and subjected to DAS-ELISA that revealed the presence of all tested viruses as shown in Table 1. 96 samples were collected in 2013 and 99 samples in 2014. 12 samples collected in 2013 and 17 collected in 2014 were infected with BCMNV, 8 and 2 with BCMV, 1 and 0 with 
BYMV and TYLCV, 2 and 1 with ToMV and CMV and 2 and 0 with TSWV (Table 1). DAS-ELISA results showed the presence of BCMNV and BCMV in all bean-producing parts around Urmia where samples were taken. BYMV, TYLCV and TSWV were only detected in Aliabad, the largest bean-growing area in Urmia. ToMV was detected in Emamzadeh-Gharachelar and Nazloo and CMV was detected in EmamzadehGharachelar and Ghafar Behi regions. Mixed infection of BCMNV and BCMV were also detected in two samples from Aliabad region. According to DASELISA results BCMNV was the dominant virus in Urmia, so one of the isolates was inoculated and monitored on Phaseolus vulgaris $\mathrm{L}$. in the greenhouse. The necrotic symptoms were seen 5 to 6 days after inoculation (Figure 2) and the presence of the virus was confirmed by DAS-ELISA.

Table 1: Incidence of seven viruses in common bean plants collected in Urmia

\begin{tabular}{|c|c|c|c|c|c|c|c|c|c|}
\hline $\begin{array}{c}\text { Place of } \\
\text { sampling }\end{array}$ & $\begin{array}{c}\text { Year of } \\
\text { sampling }\end{array}$ & $\begin{array}{c}\begin{array}{c}\text { No. of } \\
\text { samples }\end{array} \\
\end{array}$ & BCMNV & BCMV & BYMV & TYLCV & ToMV & CMV & TSWV \\
\hline \multirow{2}{*}{$\begin{array}{l}\text { Emamzadeh- } \\
\text { Gharachelar }\end{array}$} & 2013 & 15 & 4 & 2 & - & - & 1 & 1 & - \\
\hline & 2014 & 16 & 5 & 1 & - & - & - & - & \\
\hline \multirow[t]{2}{*}{ Ghafar-Behi } & 2013 & 12 & 2 & 1 & - & - & - & 1 & - \\
\hline & 2014 & 15 & 3 & 1 & - & - & - & - & - \\
\hline \multirow[t]{2}{*}{ Jabal } & 2013 & 14 & 2 & 1 & - & - & - & - & - \\
\hline & 2014 & 16 & 3 & - & - & - & - & - & - \\
\hline \multirow[t]{2}{*}{ Balo } & 2013 & 12 & 1 & 1 & - & - & 1 & - & - \\
\hline & 2014 & 13 & - & - & - & - & - & - & - \\
\hline \multirow[t]{2}{*}{ Nazloo } & 2013 & 12 & 1 & 1 & - & - & - & - & - \\
\hline & 2014 & 10 & 1 & - & - & - & 1 & - & - \\
\hline \multirow[t]{2}{*}{ Aliabad } & 2013 & 31 & 2 & 2 & 1 & 1 & - & - & 2 \\
\hline & 2014 & 29 & 5 & - & - & - & - & 1 & - \\
\hline \multirow[t]{2}{*}{ total } & 2013 & 96 & 12 & 8 & 1 & 1 & 2 & 2 & 2 \\
\hline & 2014 & 99 & 17 & 2 & - & - & 1 & 1 & - \\
\hline \multirow{2}{*}{$\begin{array}{c}\text { Rate of } \\
\text { infection }(\%)\end{array}$} & 2013 & - & 12.5 & 8.3 & 1.04 & 1.04 & 2.1 & 2.1 & 2.1 \\
\hline & 2014 & - & 17.2 & 2.1 & - & - & 1.04 & 1.04 & - \\
\hline
\end{tabular}

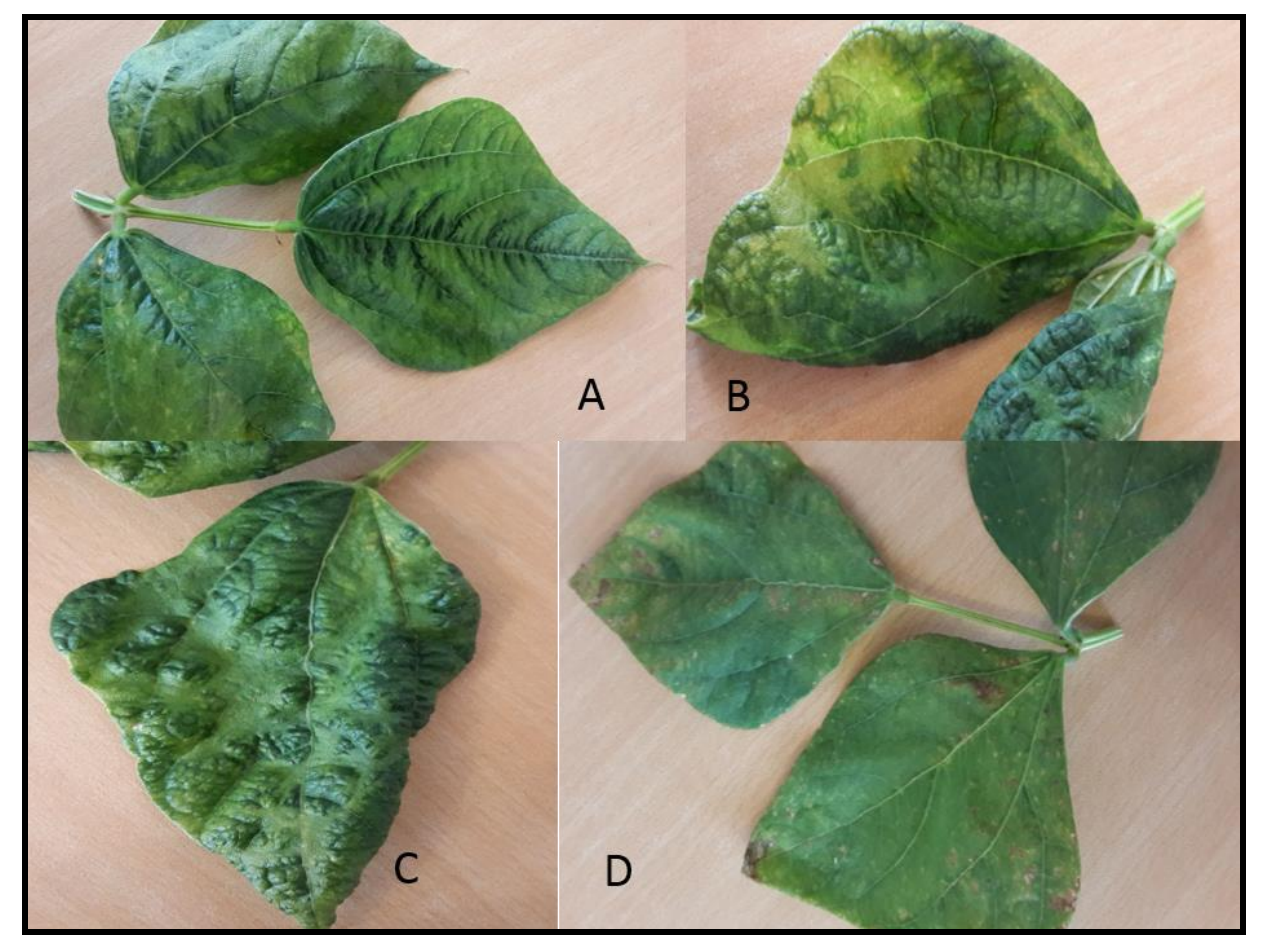

Figure 1: Symptoms of A, vein banding, B, blistering, C, mottling and D, necrosis on virus-infected bean plants 


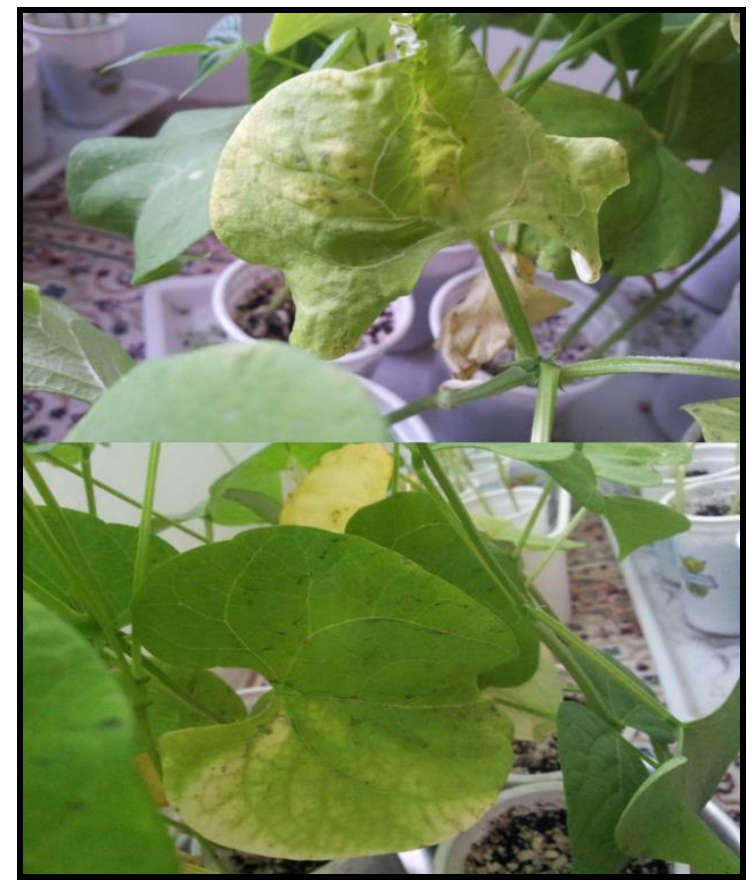

Figure 2: Necrosis induced by BCMNV after inoculation on bean

The incidence and distribution of BCMV, BCMNV, BYMV, TYLCV, TMV and TSWV in bean growing areas of Urmia were not similar to each other. BCMNV infection was the highest. As in Urmia, BCMV and BCMNV are the most prevalent viruses in common bean also in other areas of the world. Since both viruses were found in the same areas and even in the same plant, recombinations between them are possible and can lead to creation of new strains or even new pathotypes (Vallejoes et al., 2006) in Urmia.

Previous studies reported that the incidences of BCMNV strains is lower than those of BCMV strains in most bean production areas of the world (Berger et al., 1997; Kostova et al., 2003; Petrović et al., 2010), but our two year survey in Urmia bean-producing regions indicated that BCMNV is prevalent in most regions.

In most visited areas, especially in Aliabad region, high rate of viral infection was observed. DAS-ELISA test showed different infection rates in various places. The highest infection rate of BCMNV was found in Emamzadeh-Gharachelar and Aliabad probably due to virulence of this virus, high population of the vectors in these areas and suitable weather condition for infection.
TYLCV was found on common bean with a disease incidence of 50 to $70 \%$ showing thickening and crumpling of leaves and stunting in northern Anhui Province, China ( $\mathrm{Ji}$ et al., 2012). Hosseini and Eini Gandomani (2014) detected gemini viruses on bean in Zanjan province, Iran. We detected TYLCV in only one symptomatic sample in Aliabad region.

BCMNV was reported for the first time and in high abundance in Urmia indicating the spread of viral diseases with climate change and global warming. There has not been any data on occurrence and importance of viral diseases on bean and their spread in nature in the province since now. Investigation on occurrence, spread and determination of dominant viruses of bean are very important especially for implementation of proper diagnostic methods and management techniques, especially breeding for resistance. According to the local observations, symptoms of viral diseases on bean farms of this province are increasing considerably in recent years. Our results also showed high rate of virus infection in the area and confirmed these observations. 


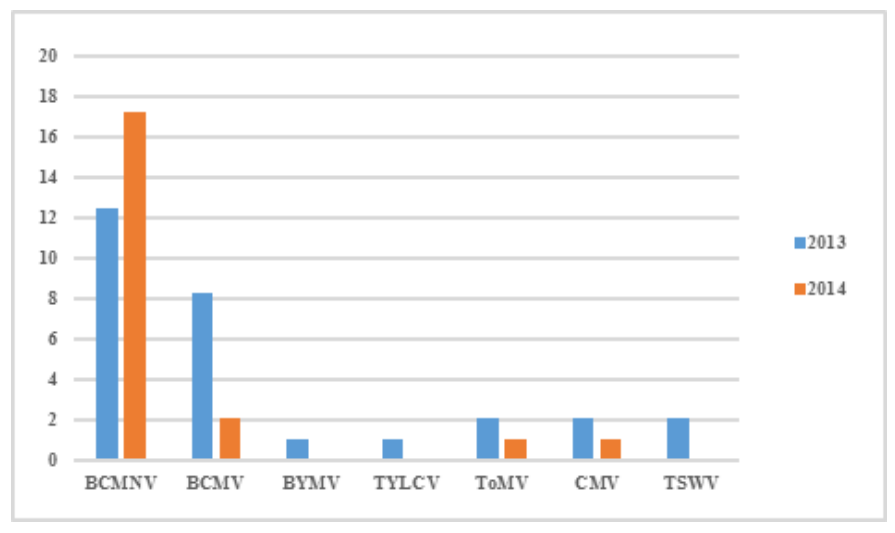

Figure 3: Percentage of incidence of BCMNV, BCMV, BYMV, TYLCV, ToMV, CMV and TSWV in bean fields of Urmia during 2013-2014 growing seasons

\section{CONCLUSION}

Viruses are known to greatly reduce bean yield. BCMV and BCMNV, two economically very important bean viruses transmitted by several aphid species and by seed, were found in high incidence in West Azarbaijan province, Urmia region using DAS-ELISA. Most of the mosaic and systemic necrosis symptoms observed in bean plants in the field could be attributed to these two viruses. Additionally, the presence of BYMV, TYLCV,
ToMV, CMV and TSWV was confirmed. To our knowledge this is the first report of TSWV incidence on bean in Iran and the first report of the presence of BCMNV, BCMV, BYMV, TYLCV, ToMV, CMV and TSWV in West Azarbaijan province, Urmia (Iran). Results of this study are the base for further work on ecology, epidemiology, diversity and breeding for resistance to bean viruses in Urmia and also in Iran.

\section{REFERENCES}

Alavi, S., and Massumi, H. (2014). Distribution, biological properties and genetic diversity of Iranian tomato mosaic virus isolates. Iranian Journal of Plant Pathology, 50 (1), 37-52.

Arli-Sokmen, M., Deligoz, I., and Kutluk-Yilmaz, N. (2016). Characterization of Bean common mosaic virus and Bean common mosaic necrosis virus isolates in common bean growing areas in Turkey. European Journal of Plant Pathology, 146, 1-16. doi:10.1007/s10658-016-0886-X

Berger, P.H., Wyatt, S. D., Shiel, P. J., Silbernagel, M. J., Druffel, K., and Mink, M. I. (1997). Phylogenetic analysis of the Potyviridae with emphasis on legumeinfecting potyviruses. Archives of Virology, 142, 1979-1999. doi:10.1007/s007050050216

Brunt, A.A, Crabtree, K., Dallwitz, M.J., Gibbs, A.J., Watson, L., and Zurcher, E.J. (1996). Plant viruses online: descriptions and lists from the VIDE database. Version: 20th August 1996. URL http://biology.anu.edu.au/Groups/MES/vide/.

Clark, M.F., and Adams, A.N. (1977). Characteristics of the micro plate method of enzyme-linked immunosorbent assay for the detection of plant viruses. Journal of General Virology, 34, 475-483. doi:10.1099/0022-1317-34-3-475

Ghobakhloo, A., Pourrahim, R., Elahinia, S.A., and Farzadfar, SH. (2012). Molecular RT-PCR detection of Bean common mosaic virus-BCMV in Melilotus sp. Proc. $12^{\text {th }}$ Iranian Genetics Congress, Tehran, Iran, pp. 70-74.

Ghasemzadeh, A., Sokhandan Bashir, N., and Khakvar, R. (2012). Identification of important viruses for Legominosae family with using of universal primers from East-Azarbaijan province. Proc. 12 $2^{\text {th }}$ Iranian Genetics Congress, Tehran, Iran, pp. 92-97.

Hosseini, V., and Eini Gandomani, A. (2014). Molecular Determination of geminiviruses of bean in Zanjan province. Proc. Iran's 21th Congress of Plant Protection. Urmia, Iran, 405.

Ji, Y.H., Cai, Z.D., Zhou, X.W., Liu, Y.M., Xiong, R.Y., Zhao, T.M., Yu, W.G., Tao, X.R., and Zhou, Y.J. (2012). First report of Tomato yellow leaf curl virus infecting common bean in China. Plant Disease, 96, 1229. doi:10.1094/PDIS-03-12-0258-PDN

Kaiser, W.J., and Mosahebi, GH. (1974). Natural infection of mungbean by Bean common mosaic virus. 
Phytopathology, 64, 1209-1214. doi:10.1094/Phyto64-1209

Kostova, D., Lisa, V., Milne, R. G., Vaira, A. M., Dellavalle, G., and Tsorlianis, S. (2003). Virus diseases of vegetable crops in Southern Bulgaria. Phytopathologia Mediterranea, 42, 3-8.

Kumar, C.A., Khetarpal, R.K., Parakh, D.B., Singh, S., and Nath, R. (1994). Check list on seed transmitted viruses: Leguminous hosts. National Bureau of Plant Genetic Resources, New Delhi-110012, 14 p.

Loebenstein, G., Tottappilly, G., Fuentes, S., and Cohen, J. (2009). Virus and phytoplasma diseases. In: Loebenstein, G. and G. Thottappilly (eds.). The Sweet Potato. Springer, Berlin, Germany. doi:10.1007/9781-4020-9475-0_8

Mavrič, I., and Šustar-Vozlič, J. (2004). Virus diseases and resistance to bean common mosaic and bean common mosaic necrosis Potyvirus in common bean (Phaseolus vulgaris L.). Acta Agriculturae Slovenica, 83(1), 181-190.

Petrović, D., Ignjatov, M., Nikolić, Z., Vujaković, M., Vasić, M., Milosević., et al. (2010). Occurrence and distribution of viruses infecting the bean in Serbia. Archives of Biological Science, 62(3), 595-601. doi:10.2298/ABS1003595P
Peyambari, M., Koohi Habibi, M., Mosahebi, GH, and Izadpanah, K. (2011). Study of bean common mosaic virus (BCMV) in several provinces and reaction of three bean genotypes to BCMV infection. Journal of Plant Protection, 25(3), 250-257.

Salari, N., Seyyed Musavi, M., Shahraeen, N., Ghorbani, Sh., and Maleki, M. (2013). Identification and diagnosis of isolates of bean common mosaic virus and bean common mosaic necrosis virus by immunocapture RT-PCR. New Cellular and Molecular Biotecnology Journal, 3(11), 21-28.

Shahraeen, N., Hassani Mehrban, A., Mostaed, M., and Ghotbi, T. (2002). Bean common mosaic necrosis virus (BCMNV) incidence report in bean farms in Arak and Lorestan provinces. Proc, Iran $15^{\text {th }}$ Plant Protection Congress, Kermanshah, Iran, p. 287.

Shahraeen, N., Ghotbi, T., Dezaje, A and Sahandi, A. (2005). A survey of viruses affecting French bean (Phaseolus vulgaris L.) in Iran includes a first report of Southern bean mosaic virus and Bean pod mottle virus. Plant Disease, 89, 1012. doi:10.1094/PD-891012B

Vallejos, C. E., Astua-Monge, G., Jones, V., Plyler, T. R., Sakiyama, N. S., and Mackenzie, S. A. (2006). Genetic and molecular characterization of the $I$ locus of Phaseolus vulgaris. Genetics, 172, 1229-1242. doi:10.1534/genetics.105.050815 